
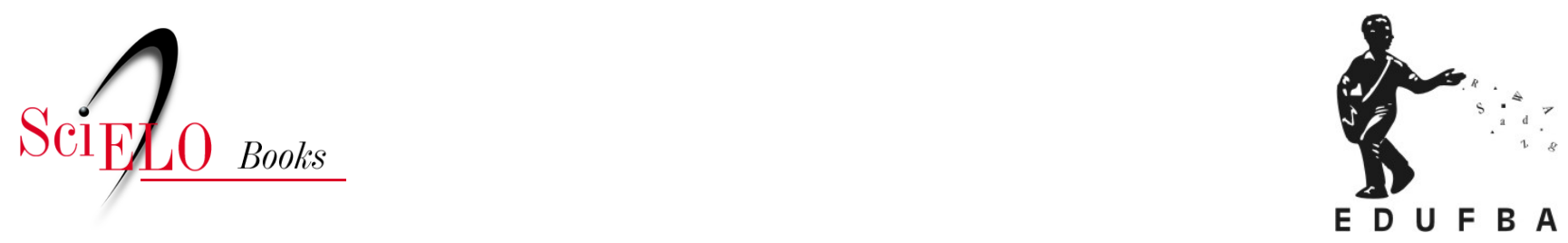

\title{
Pensar por imagens
}

\author{
Junia Mortimer
}

MORTIMER, J. Pensar por imagens. In: JACQUES, P.B., and PEREIRA, M.S., comps. Nebulosas do pensamento urbanístico: tomo I- modos de pensar [online]. Salvador: EDUFBA, 2018, pp. 146-175. ISBN 978-85-232-2032-7. https://doi.org/10.7476/9788523220327.0007.

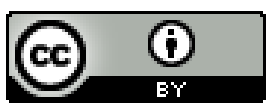

All the contents of this work, except where otherwise noted, is licensed under a Creative Commons Attribution 4.0 International license.

Todo o conteúdo deste trabalho, exceto quando houver ressalva, é publicado sob a licença Creative Commons Atribição 4.0.

Todo el contenido de esta obra, excepto donde se indique lo contrario, está bajo licencia de la licencia Creative Commons Reconocimento 4.0. 
PENSA R PO R 


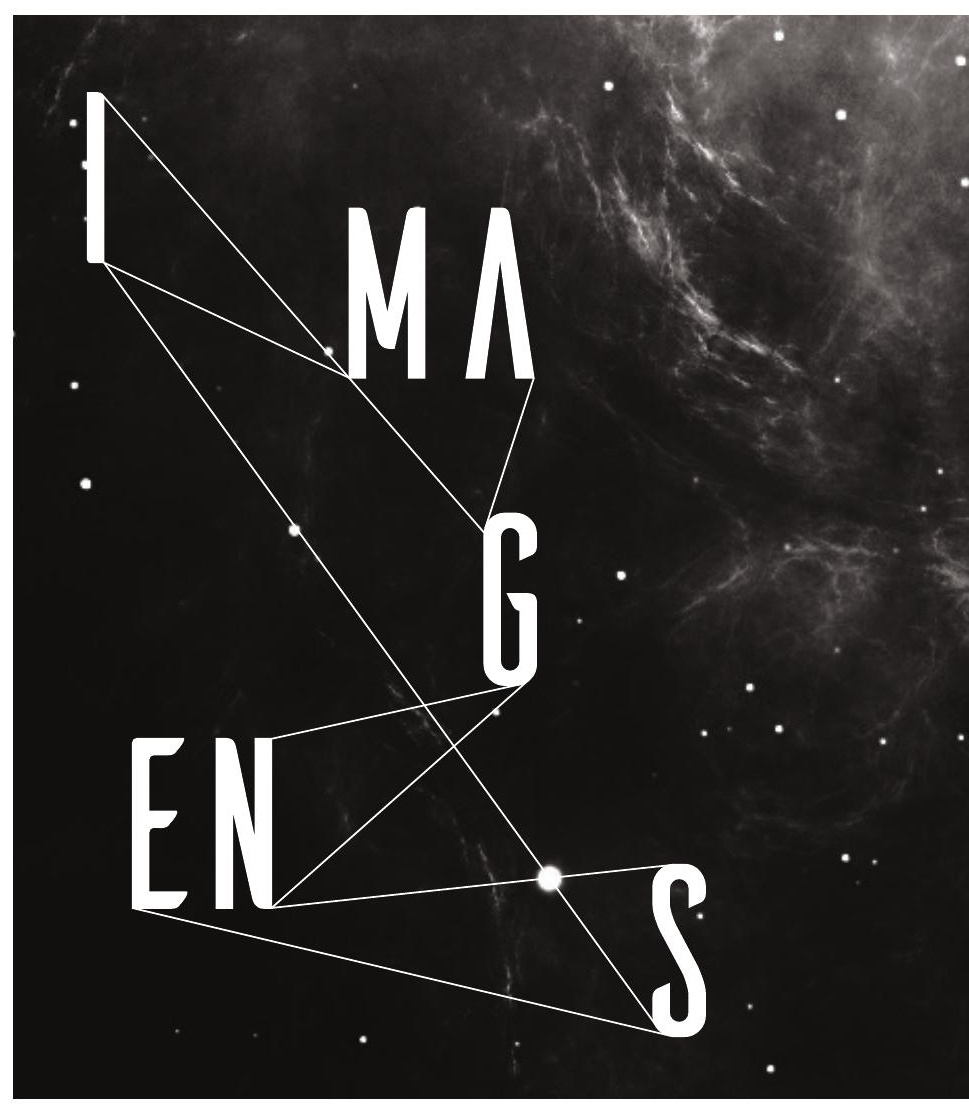




$$
\begin{gathered}
\text { PENSAR } \\
P O B \\
\text { IM } \perp E N S
\end{gathered}
$$

Do interior do retrato ao retrato do exterior ${ }^{1}$ ou diante das fotografias de Aracy Esteve (BAHIA 1950-1965)

$$
\begin{aligned}
& \text { J U N I } ~ \\
& M \quad O B T I M E R
\end{aligned}
$$


pensar por imagens junia mortimer

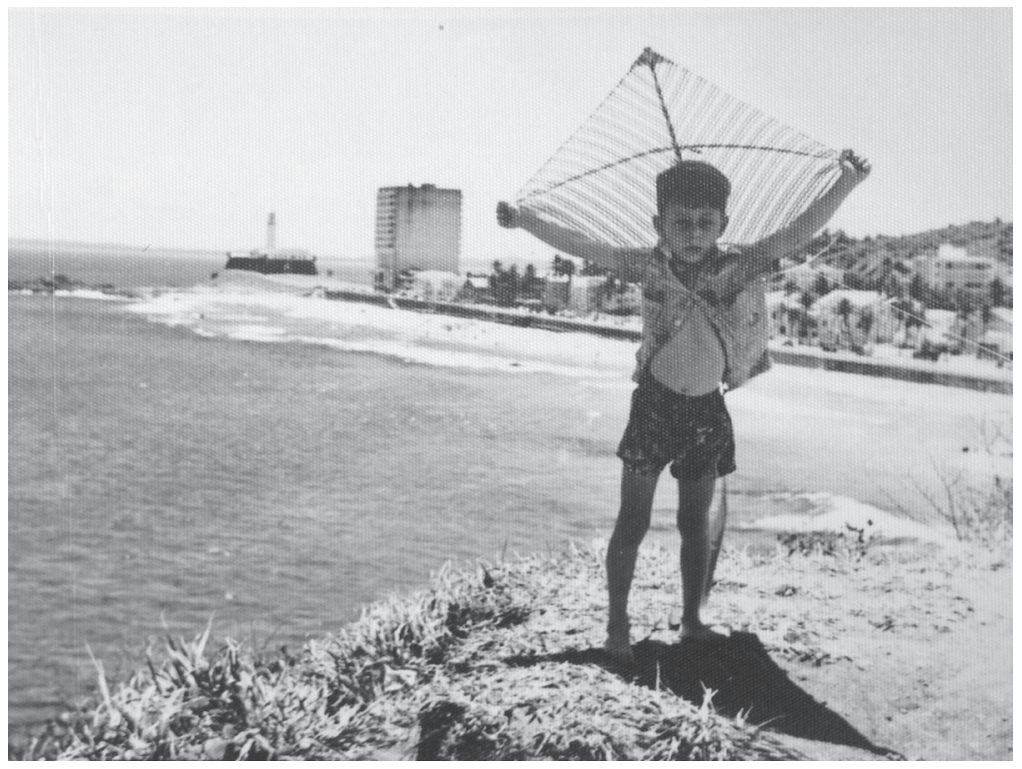

Figura 1 
nebulosas do pensamento uhanistico modos de pensar
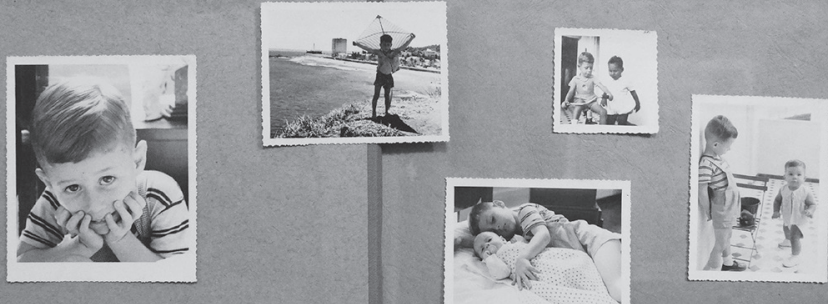

Figura 2

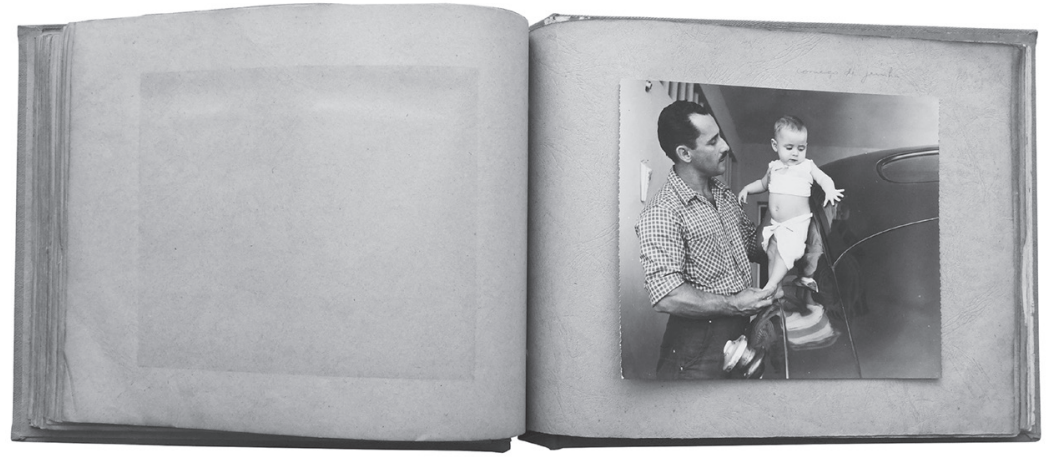

150 Figura 3 

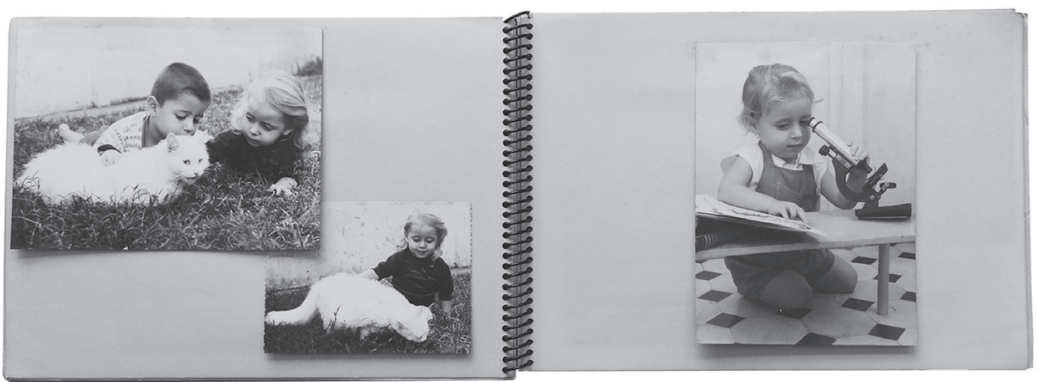

Figura 4

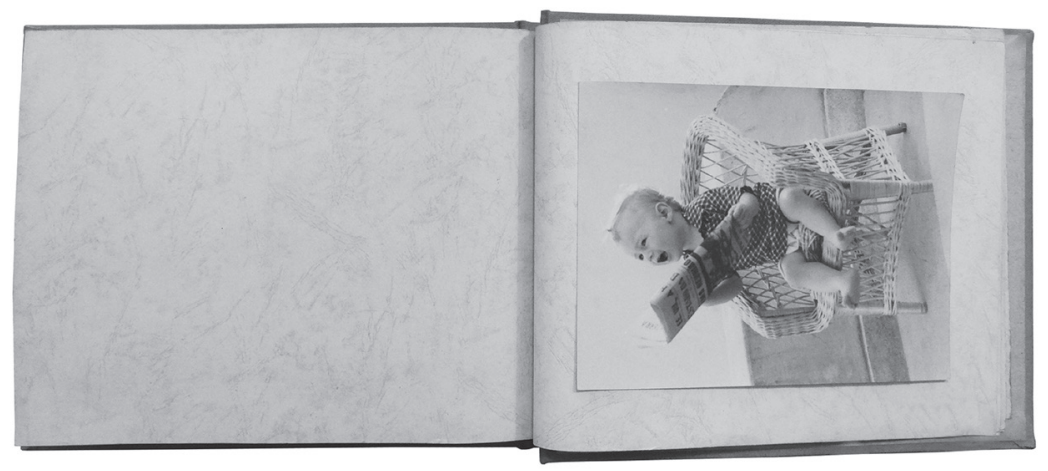

Figura 5 
nebulosas do pensamento uhanistico modos de pensar

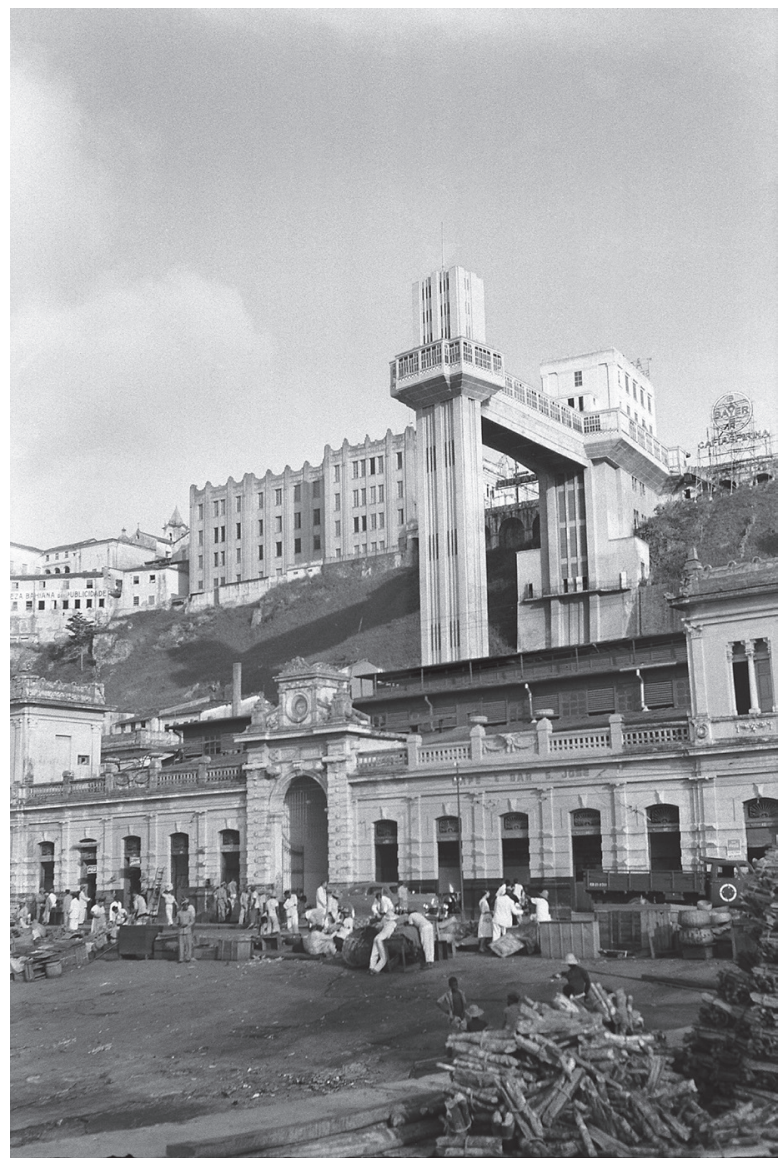


PENSAR POR IMAGENS JUNIA MORTIMER

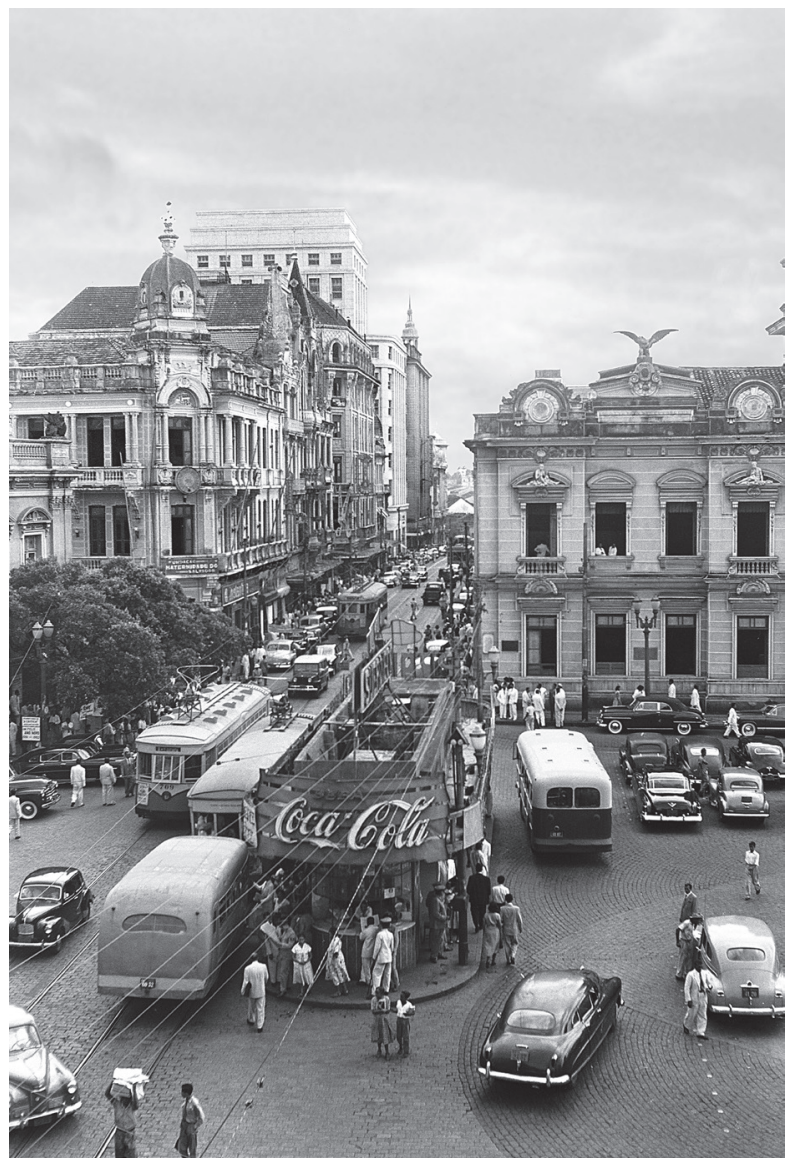

Figura 7 
nebulosas do pensamento uhanistico modos de pensar

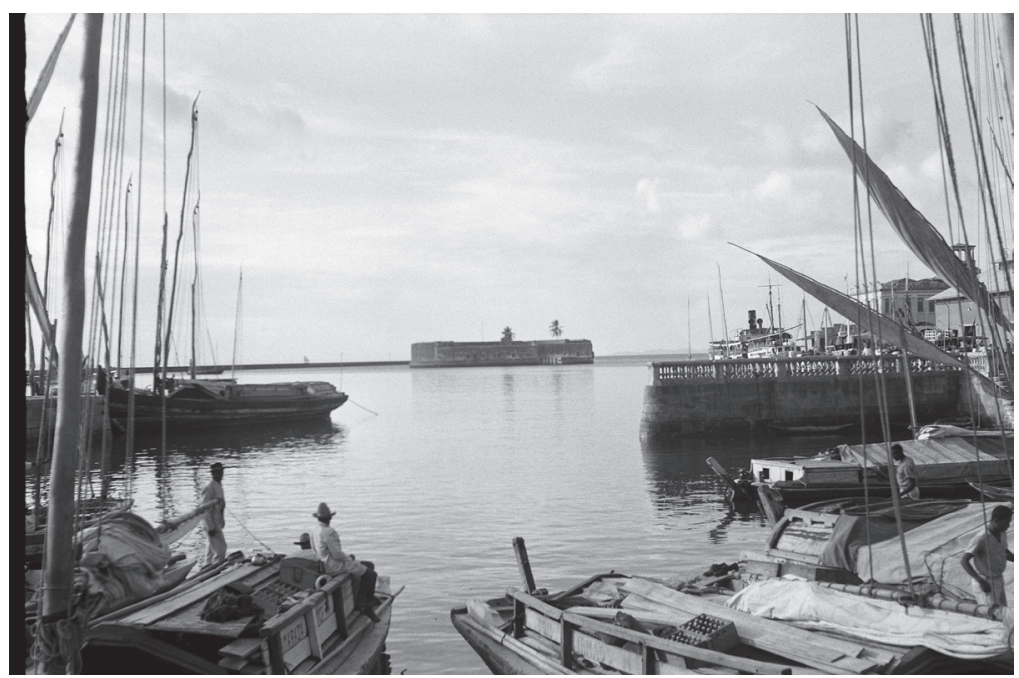

154 Figura 8 
pensar por imagens junia mortimer

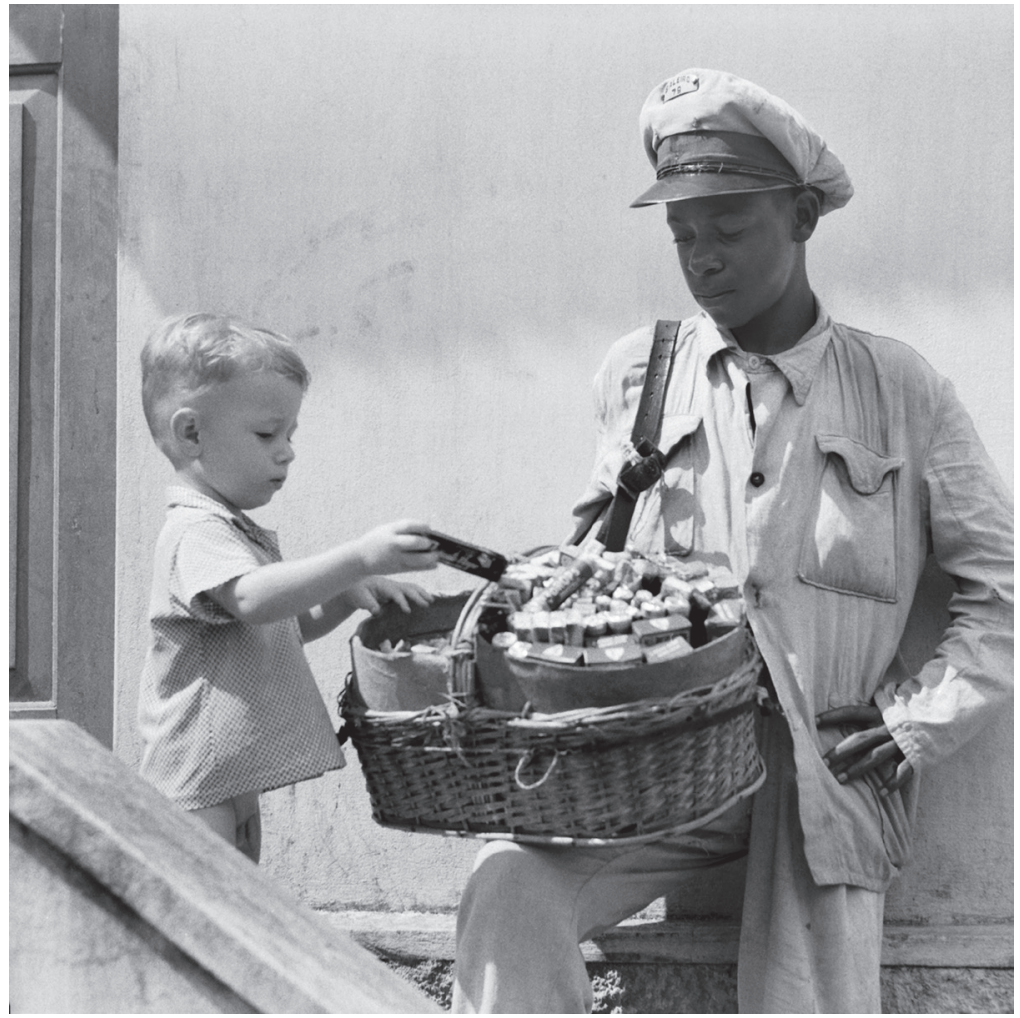

Figura 9 
nebulosas do pensamento uhanistico modos de pensab

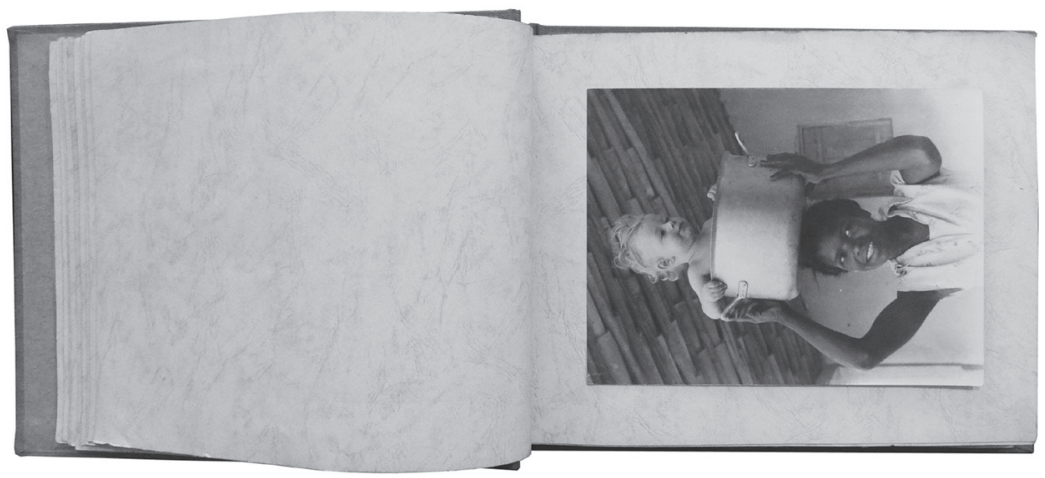

Figura 10

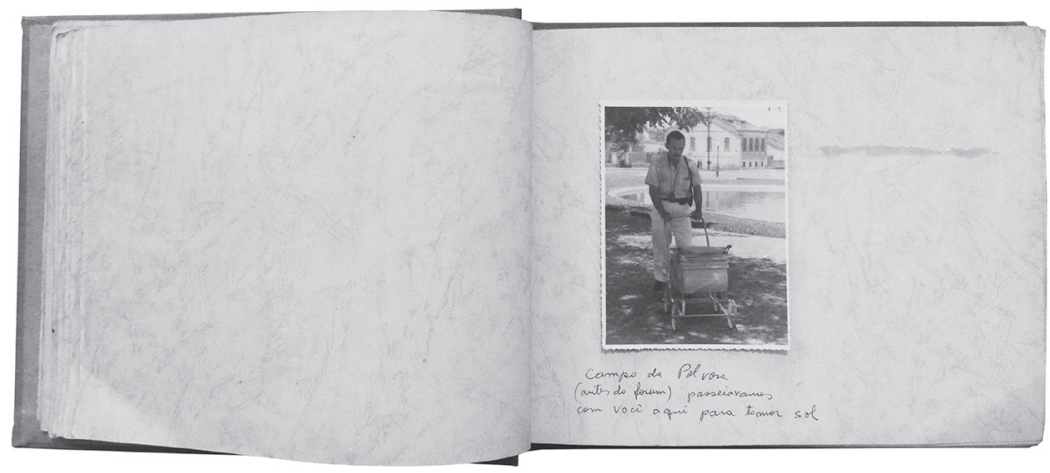

$156 \quad$ Figura 11 
pensar por imagens junia mortimer

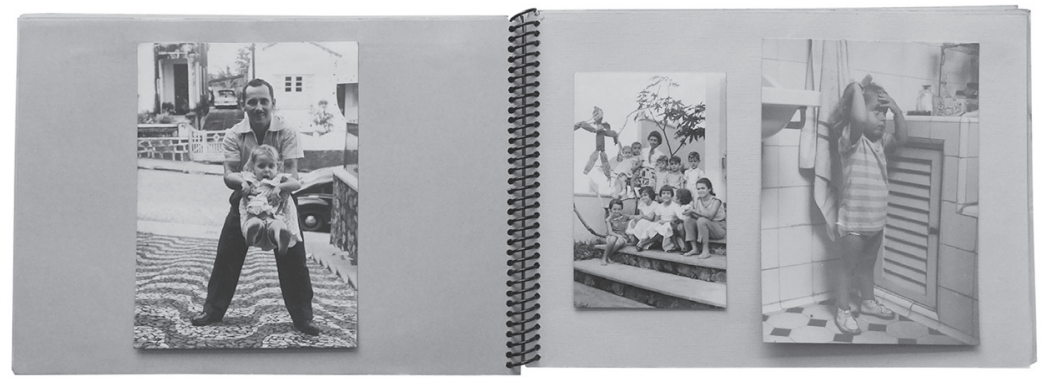

FIGURA 12
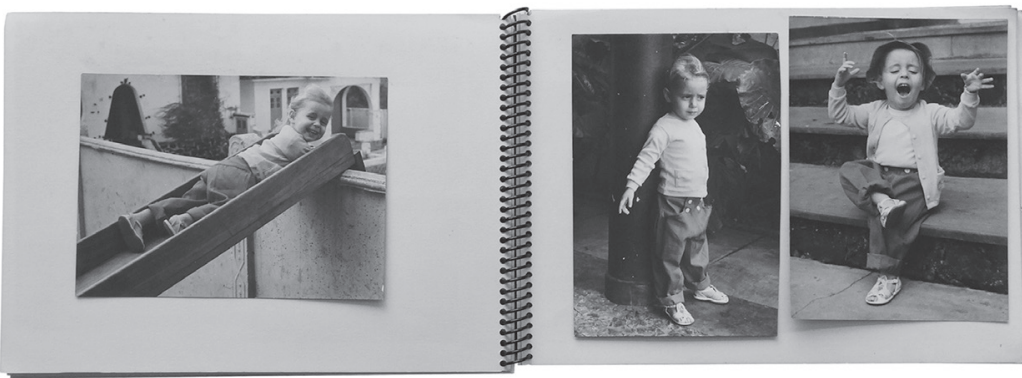

FIgURA 13 


\section{UMA IMAGEM, PONTO DE PARTIDA}

m primeiro plano (Figura 1), um menino abre os braços e segura com as mãos as pontas de um papagaio. Sua envergadura coincide com a do objeto e, entre o arco dos braços e aquele da estrutura voadora, seu rosto permanece hesitante entre suspender a brincadeira e posar para a fotografia. Ao fundo, dois símbolos arquitetônicos nos localizam geográfica e historicamente: o Farol da Barra, à esquerda, e o edifício Oceania, em frente, nos convocam até uma Salvador de meados do século XX. No alto da colina de onde a foto foi tirada, há uma estátua de Cristo, a qual não vemos na imagem. No seu lugar, temos a figura do menino. Os mesmos braços abertos. Mas se na imagem religiosa estaria a morte, na criança da fotografia está um movimento de voo. Mas um movimento suspenso na brincadeira interrompida pela rigidez da pose. Esse resíduo de voo desestabiliza a imagem: há sol, há mar, há uma cidade inteira em franco processo de modernização, mas, nos punhos cerrados e no cenho levemente franzido da criança, algo resta suspenso. Uma breve perturbação se abre entre a pretensa liberdade construída nas formas, tanto do menino-papagaio como dos símbolos arquitetônicos, e um possível cerceamento (cultural? social?) que delineia impiedosamente o limiar do possível. 
Em que medida os resíduos que vemos nessa imagem podem ser desdobrados em termos de modos de apreensão e experiência de cidade numa perspectiva histórica, talvez invisíveis em historiografias oficiais de Salvador? Que modos de apreensão de espaço, de se pensar sociedade e cultura, historicamente construídos, é possível imaginar partindo dessa fotografia inicial? E em que medida esse movimento historiográfico poderia afetar nossos próprios modos de produção e apreensão da cidade hoje?

\section{DA SINGULARIDADE DA IMAGEM FOTOGRÁFICA}

Vamos tomar, portanto, essa fotografia como nosso ponto de partida. Ela será nosso "lugar de problematização" num campo de estudos expandido que se dedica a discutir espaço, sociedade e cultura, na perspectiva da história da cidade e do urbanismo; mas com valiosas implicações também para o campo da fotografia, das artes visuais e do imaginário.

No entanto, antes de adentrar a especificidade deste nosso ponto de partida, a fotografia inicial, Boris Kossoy (2001) nos adianta dois desafios incontornáveis ao lidar com a imagem fotográfica como lugar de problematização para uma pesquisa de caráter histórico: primeiro, o fato de existir um "aprisionamento multissecular à tradição escrita como forma de transmissão do saber [...]; nossa herança livresca predomina como meio de conhecimento científico". (KOSSOY, 2001, p. 30) Segundo, o fato de, por conta desse iletramento visual, a imagem configurar-se como um obstáculo, já que a informação não é "transmitida segundo um sistema codificado de signos em conformidade com os cânones tradicionais da comunicação escrita”. (KOSSOY, 2001, p. 30)

No entanto, mesmo uma suposta educação visual, ainda assim, não daria conta, segundo Barthes (1984), de certa irredutibilidade da imagem. Mesmo que consideremos todos os aspectos culturais que conseguimos decifrar na leitura de uma fotografia, sobrevive a essa decifração uma relação com a imagem que é da ordem do mágico, do inexplicável. Essa relação, de dimensão fetichista, entre observador e imagem fotográfica é aquilo que atrai o observador, por dilacerá-lo. 
E ainda que ele não consiga explicar essa atração, segundo Barthes (1984), o observador pode narrá-la, pode compartilhá-la. Essa é a famosa dialética entre punctum e studium defendida pelo pensador francês nas suas notas sobre fotografia. Para ele, a fotografia se destaca justamente quando, na sua condição de um "isso foi”, é capaz de furar, dentro de uma esfera individual e particular, o discurso codificado da cultura (studium) e afetar o indivíduo de forma pungente e dilacerante (punctum). Barthes (1984) aposta, assim, na relação entre um discurso codificado, socialmente compartilhado e culturalmente constituído e na insuficiência desse mesmo discurso para dar conta da potência desestabilizante e transformadora abrigada na fruição individual e particular da imagem fotográfica. Vale ressaltar, portanto, que o punctum, para ele, não é algo que possa ser instituído/ institucionalizado, pois isso seria já o seu esgotamento.

Barthes (1984), no entanto, exclui do fotógrafo a habilidade de agenciar essa dialética conscientemente. Por isso, ele se debruça menos sobre o gesto de fotografar e mais sobre o gesto de fruir a fotografia. Em Barthes, essa tensão entre código cultural e magia é própria da fruição, pois o punctum é justamente o apontar de dedo (índice) para o sujeito. Segundo Dubois (2012), do mesmo modo que "isso foi” - noema da fotografia -, o é para o referente na reflexão sobre a fotografia. Desviando-se do gesto de fotografar para se concentrar nessa fruição, Barthes se debruça, no seu livro A câmara clara (1984), sobre algumas fotografias de modo a narrar e compartilhar esse dilaceramento que a imagem lhe provoca como algo que não é passível de projeto, como algo que escapa ao controle de categorias analíticas da arte, da estética, da história ou mesmo da epistemologia. E, sobretudo, como algo que emana do visível (isso foi), e não do dizível. (RANCIĖRE, 2012, p. 24)

É interessante como um semiólogo, autor de obras anteriores como Mitologias (1957), coloca em suspensão, nas breves notas de A câmara clara (1984), justamente a possibilidade de todo o letramento visual empreendido pela semiologia. Mas é chamando atenção para o irredutivel da imagem que Barthes, de algum modo, devolve a potência do visível à fotografia e recoloca no campo a dimensão da mágica, do 160 feitiço, da imago. E por isso mesmo, a fotografia, para ele, se insere 
numa determinada codificação visual ao mesmo tempo em que escapa a ela: está justamente aí a sua potência.

Essa tensão entre a codificação cultural e irredutibilidade dilacerante da imagem pode ser lida como uma dialética entre visível e dizível, segundo Rancière (2012), ou entre saber e ver, como propõe DidiHuberman (2013, p. 190) por meio da imagem de tecido e rasgadura.

Não se trata de modo algum de escolher um pedaço, de fatiar - saber ou ver [...] - mas de saber permanecer no dilema, entre saber e ver, entre saber alguma coisa e não ver outra coisa em todo caso, mas ver alguma coisa em todo caso e não saber alguma outra coisa... Em nenhum dos casos se trata de substituir a tirania de uma tese pela de uma antítese. Trata-se apenas de dialetizar: pensar a tese com a antítese, a arquitetura com suas falhas, a regra com sua transgressão, o discurso com seu lapso, a função com sua disfunção [...] ou o tecido com sua rasgadura [...].

Rasgadura como aquilo que desestabiliza as leituras estabelecidas e solicita interpretações outras, as quais a historiografia tradicional ignora o reprime:

Nessa rasgadura, portanto, trabalha alguma coisa que não posso apreender - ou que não pode me apreender inteiramente, duradouramente - pois não estou sonhando, e que no entanto me atinge na visibilidade do quadro como um acontecimento do olhar, efêmero e parcial. (DIDI-HUBERMAN, 2013, p. 204)

Essa irredutibilidade do ver, daquilo que é específico da imagem espécie de impossibilidade de codificação cultural ou desvio diante dessa codificação -, aparece também, como na teoria da imagem, como dimensão escatológica. (AGAMBEN, 2007, p. 28) A dimensão escatológica do gesto que o bom fotógrafo sabe colher, para Agamben (2007, p. 28), está no poder desse gesto colhido de "condensar e convocar ordens inteiras", de magicamente resumir em si o sentido de toda uma existência, "sem porém diminuir em nada a historicidade e a singularidade do evento fotografado". Nesse sentido, esse 
gesto colhido condensa o indício histórico e, ao mesmo tempo, pela singularidade poderosa do gesto captado, consegue "remeter a outro tempo, mais atual e mais urgente do que qualquer tempo cronológico”. (AGAMBEN, 2007, p. 28)

Agamben (2007, p. 29) complementa essa transtemporalidade da fotografia, implicada na dialética entre visível e dizível, com um outro aspecto que ele denomina como "exigência: o sujeito fotografado exige algo de nós”. Nessa exigência - que podemos relacionar com a "solicitação de interpretar", proposta na rasgadura de Didi-Huberman (2013) -, Agamben (2007) não vê nada de estético nem de documentação de evento, isto é, não se trata de algo da ordem dos códigos culturais ou de um simbólico estabelecido no imaginário. Agamben (2007, p. 29) identifica essa exigência como exigência de redenção: "aquela pessoa, aquele rosto exigem o seu nome, exigem que não sejam esquecidos”. Profecia do corpo glorioso, Agamben (2007) conclui, portanto, que a imagem fotográfica é um gesto que historiciza na sua singularidade, dentro de uma dimensão cultural, mas que também exige uma redenção. Redenção não necessariamente como algo que nos escapa de qualquer conhecimento dos códigos culturais (como seria o punctum segundo Barthes), mas algo que escapa ao que é já sabido, ao que é já estabelecido, e que coloca em evidência o descarte, o resto; o interstício, a margem, o infame e o afogado. É nesse sentido que ele a entende como "o lugar de um descarte, de um fragmento sublime entre o sensível e o inteligível, entre a cópia e a realidade, entre a lembrança e a esperança”. (AGAMBEN, 2007, p. 29)

Flusser (2011) concorda com esse jogo entre códigos culturais que está implicado na atividade de fotografar quando se dedica sobre o gesto de fotografar - se Agamben (2007) prioriza o gesto colhido pela objetiva, Flusser (2011) enfatiza o gesto do fotógrafo. Focando-se menos na fruição da fotografia, como Barthes, e mais na produção da imagem fotográfica, o autor argumenta que o fotógrafo, engranzado numa selva de códigos culturais, busca desviar-se deles para produzir suas imagens. Diante da selva de objetos culturalmente construídos, o gesto de fotografar implicaria um desvio com relação a esse sistema de símbolos: "Os caminhos tortuosos do fotógrafo visam driblar as 162 intenções escondidas nos objetos. Ao fotografar, avança contra as 
intenções da sua cultura”. (FLUSSER, 2011, p. 49) Nesse sentido, fotografar seria também rasgar um certo véu da cultura.

Mas o rasgar deste véu se dá, ao mesmo tempo e invariavelmente, por meio da constituição de outro véu, aquele de um mundo imaginário, no sentido de um mundo constituído por imagens, "[...] mundo das fotografias, dos filmes, do vídeo, de hologramas, mundo radicalmente inimaginável para as gerações precedentes”. (FLUSSER, 2008, p. 41-42) $O$ gesto de fotografar, no anseio de desviar-se das intenções escondidas no véu da cultura, constitui um outro véu, aquele da superficialidade que caracteriza, para Flusser (2008), o universo das imagens técnicas no qual vivemos inseridos. E esse véu exige outro tipo de entendimento que, para ele, como para Kossoy (2001), não é aquele do pensamento linear da escrita. Trata-se de um outra lógica, porque se insere num outro regime, o regime de visibilidade, cujas formas de aproximação não são aquelas do texto nem da escritura.

A partir de uma genealogia simplificada sobre a relação imagem e escrita, Flusser (2008, p. 16) aborda o que Kossoy chama de "aprisionamento multissecular da tradição da escrita" como o desdobramento de uma necessidade de se controlar as imagens (as pictóricas, as imagens não técnicas): para controlar essa inteligência da imaginação, de natureza distanciada (um passo atrás para criar uma cena) e mágica (ritualística), teria sido instituído um pensamento linear, processual, explicativo, que é o pensamento da escrita. Nesse esforço de controle das imagens estaria um combate ao risco da alienação e da idolatria por meio da explicação da imagem - uma forma de controle - colocando-a, portanto, como ilustração do texto ou restringindo-a a lugares específicos - outra forma de controle: museus e galerias.

Se na tradição ocidental as imagens ficaram submetidas por muito tempo à escrita, admitidas nos livros como ilustrações, portanto, domadas e controladas, Fontcuberta (2016, p. 11) lê o excesso de imagens que vivenciamos hoje como uma revolta, uma insurgência, uma insubmissão das imagens ao controle que lhes foi imposto. Mas essa insubmissão configura um território de disputa por visibilidade que acontece sem uma consciência crítica sobre o poder das imagens, 
sobre o poder do conhecimento construído nessa base e de como isso nos afeta. É uma disputa da qual participamos mas cujos códigos desconhecemos ou com o quais temos muito menos intimidade. $\mathrm{O}$ que implica, portanto, nesse contexto de insubmissão pelo excesso tomar uma imagem como ponto de partida para um estudo historiográfico? Quais os riscos desse movimento?

Flusser (2008) complexifica ainda mais a questão colocando o argumento de que as fotografias não são ontologicamente equivalentes às imagens pictóricas, que foram controladas pelo pensamento linear e processual da escrita. Elas são imagens técnicas, produzidas por meio de um aparelho e, portanto, resultantes de um conceito, de uma escrita. No entanto, essa dimensão do aparelho foi progressivamente apagada da fruição dessas imagens justamente para continuar a lhes atribuir o caráter aurático ou mágico das imagens não técnicas. Nessa equivalência, tendemos a não considerar o condicionamento da aparelhagem para a construção de diferentes regimes estéticos, regimes de visibilidade. Ainda assim, considerar a aparelhagem não significa anular o caráter mágico que essas imagens alcançam à revelia da diferença ontológica que as separa das imagens não técnicas. $\mathrm{O}$ punctum de Barthes (1984) aponta nessa direção, e igualmente o faz o próprio jogo de códigos culturais que Flusser explora no gesto de fotografar. Para Flusser (2011, p. 65), enquanto não levarmos em consideração essa ambiguidade do código fotográfico, a intenção do aparelho prevalecerá sobre a intenção humana.

Dessas considerações sobre este objeto que tomamos como ponto de partida de nossa reflexão, uma fotografia, ficam algumas provocações para trabalhar a imagem fotográfica como lugar de problematização para apreender a malha de urbanidade de outros momentos históricos. Essas provocações nos inserem num lugar de discussão que tenta ao mesmo tempo fazer avançar nossos conhecimentos sobre a cidade de Salvador, sem, no entanto, ignorar ou abrir mão do potente debate que está atrelado à imagem fotográfica: como desdobrar um conhecimento de história das cidades cientes das questões inerentes à condição dialética da fotografia, nosso ponto de partida? Como explorar sua natureza de evidência histórica, cujos signos podem ser 164 interpretados semiologicamente, explicados e, ao mesmo tempo, não 
perder de vista seu caráter mágico, herdado das imagens pré-técnicas e de uma intencional anulação do aparelho, para que a mágica continue a acontecer? Como atravessar o iletramento visual sem ignorar a especificidade da imagem técnica? Como trabalhar as intencionalidades (códigos) do fotógrafo (o gesto de fotografar que dribla os códigos culturais) em relação à codificação (intencionalidades) do aparelho, em função de outras historiografias urbanísticas possíveis?

\section{DiANTE Do ARQUivo, DIANTE DA CIDADE}

A fotografia que abre este texto pertence ao acervo pessoal de Aracy Esteve Gomes, mulher, mãe, professora de matemática e fotógrafa amadora residente em Salvador desde meados do século XX. Encontrei este retrato, no qual vemos seu filho, Arlindo Esteve Gomes, solto na primeira página de um dos álbuns de família (Figura 2) do seu acervo. ${ }^{2}$ As fotografias de Aracy estão, portanto, organizadas dentro de uma estrutura linear e de dimensão privada, aquela do álbum de retratos/álbum de família. Dentre as várias imagens que compõem este acervo, interessam-nos algumas: aquelas que, como fagulhas de visibilidade, atravessam a dimensão privada e estrutura cronológica do álbum e nos impelem a pensar sobre a Salvador daquele momento histórico.

Na primeira breve conversa que tivemos, ${ }^{3}$ Aracy, hoje com 94 anos, pontuou reiteradamente dois aspectos principais na narrativa que ela construiu pelas suas fotografias: primeiro, a sua relação visceral com a câmera - "vivia com a câmera pendurada no pescoço, para baixo e para cima na cidade" -; e segundo, a positividade de sua postura feminista - "era uma mulher à frente do seu tempo". Quando dirigia, "todo mundo olhava, porque não era hábito mulher dirigir naquele tempo". A fotografia do menino com a pipa, realizada por Aracy, parece reforçar essa narrativa: mulher e filho aventurando-se juntos numa cidade que se aventurava pela modernização.

Ao estudarmos essa fotografia ou nos concentrarmos no seu dizível, no seu studium, notamos a caracterização urbanística da orla na praia do Farol, ainda ocupada por generosas residências unifamiliares. Ao 
fundo, o edifício Oceania parece debutar sua presença na paisagem, e, em frente a ele, a histórica construção do Farol marca o início da Baía de Todos os Santos. Mas, para continuar nos termos de Barthes, o que me atravessa e me perfura dessa fotografia, isto é, o que emerge como punctum - a porção irredutível do visível - é a sutil suspensão presente no gesto do menino com a pipa. Algo aí vacila, ainda que a construção visual sugira, ao contrário, o voo obstinado de uma cidade em direção ao progresso. Atento-me a essa primeira emergência dentro do acervo de Aracy, a esse "ponto de surgimento" ou "lugar

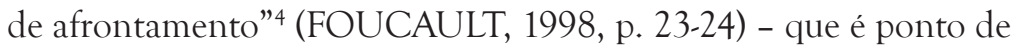
partida para a constelação de imagens que configura este texto.

Em outras fotografias do arquivo de Aracy, encontramos argumentos visuais que remetem a essa narrativa que ela construiu por suas imagens: numa delas (Figura 3), pai e filha deslumbram-se com o brilho lustroso da lataria do automóvel, o moderno e precioso bem da família; noutras (Figura 4), a filha observa desinteressada um microscópio de brinquedo, vestígio simbólico de uma fé indelével no espírito científico, ou o filho manipula um jornal (Figura 5), sentado numa poltrona, forjando gestos de leitura informativa, resquícios de uma crença nos fatos jornalísticos e na verdade que eles revelariam sobre o mundo e as atualidades. Em todas, sobrevive um maravilhamento com objetos e hábitos modernos, nos quais se parece depositar uma esperança de novos ares.

Historicamente, essas fotografias do acervo de Aracy, organizadas nos álbuns de retrato/álbuns de família, também por ela produzidos, localizam-se, em sua maioria, entre os anos de 1950 e 1965. O período é demarcado pelo nascimento de seu primeiro filho, Arlindo, e pela adolescência da filha, Núria. As crianças mobilizaram Aracy a fotografar. E ao se colocar a fotografá-las, como mãe, Aracy teria, primeiramente, dado continuidade à habilidade que aprendera com o pai, José Esteve, imigrante espanhol, também fotógrafo amador, em cujo acervo estão inúmeras fotografias realizadas em Santo Antônio de Jesus, no interior da Bahia, nas décadas de 1920 e 1930. E teria mesmo ido além, explorando essa habilidade como sujeito feminino emancipado, mulher ativa no mundo público da cidade, "à frente 166 de seu tempo". 
Foi provavelmente esse imaginário de mulher enquanto figura pública e emancipada, à frente de seu tempo, quem produziu algumas fotografias bastante simbólicas dos processos de transformação urbana da Salvador daquele período:

Adulta, foi das poucas mulheres a dirigir sozinha - 'independente' - pela cidade. Registrou preciosidades, como o Dique do Tororó margeado por uma horta imensa; a orla da Barra, em que o edifício Oceania reinava; a fachada do antigo Mercado Modelo, à frente do Elevador Lacerda. 'A foto do abrigo de bondes da Rua Chile, eu tive que implorar para o homem da Confeitaria Triunfo me deixar subir no prédio para fazer. Contei minha toda, teimei, e ele deixou.' A foto traz um ponto de vista raro, já que o prédio não existe mais - que dirá o abrigo. ${ }^{5}$ (SANGIOVANNI, 2012, p. 22)

Nesse conjunto de imagens, que, no entanto, não são numerosas no acervo de Aracy, vemos fotografias bastante diretas, descritivas do meio urbano, sobretudo do centro antigo (Figuras 6 a 8). Mas a singularidade delas no acervo (não há vestígios de repetição de ângulos, da sequencialidade de tomadas) sugere tratar-se de momentos mais raros e de movimentos rápidos, breves, quase como pequenos roubos, e provavelmente menos habituais à fotógrafa. Ainda que o percorrer a cidade acompanhe a narrativa de Aracy quando ela fala de suas fotografias - ou a partir delas -, a cidade, dessa maneira descritiva e direta, talvez não tenha sido a paisagem que mais atraiu as lentes da fotógrafa. Ou não o foi mais que as crianças, e talvez por isso as fotografias da cidade enquanto espaço público apareçam em menor número no acervo da fotógrafa amadora - mas não com menor intensidade.

Vale observar que frequentar o centro antigo, nesse período histórico, poderia ser, para determinada classe social, um movimento que implicaria convivências tidas como indesejáveis:

Em função dos diversos projetos realizados para a cidade e o redirecionamento do crescimento para a região nordeste de Salvador, da migração das principais atividades administrativas, 
comerciais e serviços e da facilidade de acesso à nova área do Iguatemi e da Avenida Tancredo Neves, o centro tradicional entra em decadência, transformando-se numa área residencial de baixa renda, marginalidade e prostituição e numa área comercial para as classes baixas - Avenida Sete de Setembro e Baixa dos Sapateiros. (PINHEIRO, 2011, p. 294)

É bastante sugestivo, portanto, de acordo com uma determinada historiografia urbanística de Salvador, a relação entre a decadência do centro, tanto o centro antigo quanto o Comércio, seu usufruto pelas classes baixas e a escassez de fotografias urbanas no acervo de Aracy. Como membro de uma classe social mais abastada - a posse da casa no Barbalho, da casa em Mar Grande, o carro e a própria câmera são indicativos do estatuto social de Aracy e de sua família -, esse trânsito urbano poderia ser uma prática evitada e, por isso, haveria menos fotografias desses lugares no arquivo de Aracy. Mas seria precipitada a conclusão: a família do esposo de Aracy, Arlindo Gomes, era proprietária de um casarão no Comércio, ${ }^{6}$ onde funcionava a loja "Gomes \& Barbosa”, gerenciada pelo sogro de Aracy entre as décadas de 1930 e 1960 (a loja fechou em 1967). Nessa mesma rua, teria ainda funcionado a loja "Argos", que o esposo de Aracy e a própria Aracy teriam administrado entre 1957 e 1967, antes de o marido se dedicar integralmente à escultura. Logo, não seria necessariamente por Aracy não frequentar esses lugares centrais - em processo de estigmatização e mudança de perfil de ocupação, seja o Centro Antigo, o Comércio ou outros ambientes urbanos - que haveria menos fotografias urbanas no seu acervo; mas talvez por não se sentir suficientemente à vontade para fotografá-los com tanta frequência, seja pela exposição do sujeito fotógrafo - sobretudo para uma fotógrafa naquele momento histórico numa Salvador tão patriarcal -, seja por uma possível sensação de insegurança diante da estigmatização do local em virtude da vulnerabilidade social dos marginalizados.

Já no que concerne às fotografias que Aracy realizou de seus filhos, estas sugerem tratar-se de um hábito frequente, realizado com o zelo e o maravilhamento de um olhar desperto pelo desestabilizar de ordem provocado pelas crianças e seduzido pela emocionante 168 trajetória de crescimento delas. Um olhar que, ao visibilizar felizes 
peripécias infantis, faz, talvez inconscientemente, emergir no interior do retrato, na proximidade da foto de família, "[...] um não-lugar, uma pura distância, o fato que os adversários não pertencem ao mesmo espaço”. (FOUCAULT, 1998, p. 24)

A cidade, como emergência e enquanto complexa malha de relações sociais, aparece nas imagens de Aracy, mas "[...] ninguém é responsável por [essa] [...] emergência; ninguém pode se autoglorificar por ela; ela sempre se produz no interstício". (FOUCAULT, 1998, p. 24) E essa cidade aparece, contrariamente, menos nas furtivas fotografias urbanas, que apresentam o antigo Mercado Modelo e o Elevador Lacerda (Figura 6), a Rua Chile (Figura 7) ou os saveiros no cais (Figura 8) e mais nos restos, nos vestígios de urbanidade que atravessam a redoma da vida privada, perfuram a casca de proteção quase alienante da classe média e instalam, no teatro da imagem, a mesma peça:

Em certo sentido, a peça representada nesse teatro sem lugar é sempre a mesma: é aquela que repetem indefinidamente os dominadores e os dominados. Homens dominam e é assim que nasce a diferença dos valores; classes dominam e é assim que nasce a ideia de liberdade [...]. (FOUCAULT, 1998, p. 24-25)

É essa cidade, enquanto malha de urbanidade, tecido de relações sociais de disputa e dissenso, palco e personagem de diferentes modos de apreensão e produção do meio que vislumbramos no destemido e cordial enfrentamento entre o menino e o baleiro (Figura 9) ou, mais incisivamente, no gesto da babá de levantar o menino dentro de uma panela ou bacia (Figura 10). Talvez em princípio inofensivos na sua despretensão cotidiana e gratuita, esses gestos fotografados pela mãe, muito provavelmente visando eternizar as descobertas da criança, são indícios históricos que recolocam no presente os traços, as marcas de um processo brasileiro e soteropolitano de formação social excludente e injusto.

Os gestos fotografados tornam-se, como vimos, segundo Agamben (2007, p. 29), um pedido de que nos lembremos. Não necessariamente da criança, que é o motivo inicial do gesto fotográfico da mãe, mas sim daqueles que não conseguimos descobrir o nome, cujos destinos 
os donos do acervo desconhecem, e de quem, num movimento a contrapelo, procuramos saber mais: o baleiro e a babá; ou, nos termos de Foucault, os infames, os que foram colocados à margem, os vencidos. Os historicamente afogados.

A emancipação feminina de Aracy, que, por um lado, relaciona-se ao gesto de dirigir sozinha na Salvador de meados do século XX, ao gesto de dar aulas de matemática ou ao gesto de empunhar a câmera para baixo e para cima na cidade, incide, por outro lado, nesse gesto mesmo de fotografar o interior do retrato de modo a visibilizar ali o retrato de um exterior. ${ }^{7}$ Nas fotografias que compõem o álbum de retratos, construção de uma dimensão privada, interior e familiar, encontramos os resíduos daquilo que excede essa dimensão; resíduos que dialética e simultaneamente condicionam essa dimensão e a superam: vestígios históricos de uma malha de urbanidade, exterior ao retrato, marcada por enfrentamentos. Enfrentamentos entre uma suposta libertação ou emancipação depositada na modernidade e nos seus símbolos e uma incontornável fragilidade dessa mesma narrativa, construída numa base histórica socialmente injusta e excludente na qual ainda vislumbramos a rica lentidão de uma urbanidade provinciana.

Se, portanto, de um lado, Aracy colhe pela objetiva os gestos de uma cidade que se lança ao progresso segundo uma lógica de exclusão e na qual sobrevivem hábitos e costumes locais que afrontam a ideia de civilização universal implicada na modernidade, de outro, o seu próprio gesto de fotografar já é um enfrentamento. Considerando o aspecto patriarcal da sociedade soteropolitana, não seria vão observar o apego de Aracy, na conversa que tivemos e em outras entrevistas da fotógrafa, ${ }^{8}$ à narrativa de emancipação e autonomia feminina construída em torno das singulares fotografias urbanas de seu acervo. Tão forte teriam sido essas experiências que elas parecem ter crescido na memória a ponto de superar um lugar do feminino que aparece, na maior parte das fotografias de Aracy, às margens do espaço público e bastante interiorizado.

Raras são as fotografias nas quais as crianças aparecem em espaços 170 públicos (Figura 11), e mesmo nessas, pouco se vê do entorno; mas 
não raras são as fotografias realizadas à porta da casa no Barbalho, onde a família residiu durante grande parte do período entre 1954 e 1969. Em uma dessas fotografias (Figura 12), Arlindo Gomes, o pai das crianças e esposo de Aracy, aparece de costas para rua, com a filha Núria pendurada nos braços. No último plano da fotografia, colhemos resquícios da Salvador de outro tempo, em meados do século XX, quando predominavam naquela região da cidade residências unifamiliares e gradis de baixa altimetria, algumas das quais resistem ainda hoje. Há um sutil e tenso limiar entre dentro e fora, entre o interior do retrato e o retrato do exterior, entre o desejo feminino de emancipação e a lei masculina de uma sociedade patriarcal.

Na fotografia vizinha a essa, na página à direita do álbum, Aracy está sentada na escadaria de entrada rodeada pelos filhos e outras crianças. Ao fundo, o boneco de Judas anuncia a festividade de sua queima. Ainda que o objeto anuncie uma festa pública, a mulher está nesse umbral, nesse limite, numa potência de vir a ser, num movimento de lançar-se ao espaço público da cidade, que é, ainda que simbolicamente, muito cerceado. Nesse limiar, a filha brinca de escorrega (Figura 13) e, no gesto de fotografar da mãe, subleva-se um desejo latente de liberdade, uma exigência, novamente nos termos de Agamben, para não nos esquecermos desse feminino histórico, insubmisso dentro dos seus padrões, por trás dessas imagens.

\section{CONSIDERAÇÕES FINAIS}

Voltemos à fotografia inicial, aquela do menino com a pipa. Nosso ponto de partida. Em todo acervo de Aracy, essa é uma das únicas imagens na qual observamos um retrato no qual a criança aparece numa tomada com ângulo mais aberto, mostrando também a cidade de Salvador. É uma fotografia na qual o retrato, hábito de uma dimensão interior em Aracy, se abre para aquilo que é o fora de suas imagens, a paisagem urbana. Abre-se, assim, espaço para imaginar a aventura de mãe e filho em descobrir a cidade e fotografar. Mas a singularidade dessa fotografia no acervo de Aracy como também a escassez de fotografias da cidade sugerem que a abertura para a aventura urbana fica, de algum modo, suspensa, atualizando-se sutil e 
quase invisivelmente em lampejos, pequenas rasgaduras que perfuram as relações socioespaciais e iluminam a malha de urbanidade que constituía Salvador.

Procurar por esses lampejos visuais em arquivos que se façam disponíveis é uma proposta de pensar por imagens a fim de chegar a outras possibilidades historiográficas do urbano e das cidades. Este texto é um gesto inicial nessa direção a partir do arquivo de Aracy. Um gesto ainda incipiente, frágil e estranho, mas talvez por isso tanto mais necessário e válido. 


\section{NOTAS}

1 O título deste artigo é inspirado na exposição realizada pela Pinacoteca do Estado de São Paulo, entre junho e outubro de 2012, intitulada "Do retrato interior ao exterior do retrato - Coleção Aracy e José Esteve”. A exposição, com curadoria de Diógenes Serra Moura dos Santos, reuniu fotografias de José Esteve, a maior parte realizada em Santo Antônio de Jesus, entre 1920 e 1930, e de sua filha, Aracy Esteve Gomes, a maior parte realizada em Salvador, Mar Grande e na fazenda do marido, Arlindo Gomes, em Canabrava, entre 1950 e 1970. A pesquisa do acervo fotográfico de Aracy Esteve é parte do projeto "Imaginários e visibilidades: práticas urbanas em fotografias soteropolitanas (1940-1970)" e "Cronologia do Pensamento Urbanístico - campo de debates sobre popular", por mim coordenados, desenvolvidos no âmbito do grupo de pesquisa Laboratório Urbano, no Programa de Pós-graduação em Arquitetura e Urbanismo da Faculdade de Arquitetura da Universidade Federal da Bahia (PPGAU/FAUFBA).

2 As fotografias do acervo de Aracy são retratos provenientes desses álbuns de família. Várias páginas já foram alteradas para digitalização com fins expositivos e os álbuns estão, portanto, alterados com relação às montagens iniciais. $\mathrm{O}$ conjunto de imagens deste texto mistura fotografias que realizamos dos álbuns de famílias e também cópias digitalizadas que nos foram gentilmente cedidas pelo filho de Aracy, Arlindo Esteve Gomes, que nos abriu as portas para conhecer esse impressionante acervo de imagens.

3 Conversamos com Aracy em agosto de 2017. A pedido do filho, Arlindo Esteve Gomes, essa primeira conversa não foi gravada. O conteúdo que mencionamos é, portanto, resultado de anotações e considerações posteriores a esse momento, no qual estávamos presentes Aracy, seu filho, Arlindo, o doutorando do PPG-AU/UFBA Cícero Menezes, também integrante do grupo de pesquisa Laboratório Urbano, e eu.

4 Segundo Foucault (1998, p. 23-24), emergência "é o princípio e a lei singular de um aparecimento [...]. A emergência se produz sempre em um determinado estado de forças. [...] A emergência é portanto a entrada em cena das forças; é sua interrupção, o salto pelo qual elas passam dos bastidores para o teatro, cada uma com seu vigor e sua própria juventude. [...] a emergência designa um lugar de afrontamento [...] um não lugar, uma pura distância”.

5 Trecho extraído da entrevista de Aracy realizada pelo jornalista Ricardo Sangiovanni, para o caderno "Muito", do jornal A Tarde, em de junho de 2012. 
6 Segundo o filho de Aracy, Arlindo Esteve Gomes, a loja "Gomes \& Barbosa” ficava na Rua Lopes Cardoso, n 29, no Comércio, e teria funcionado de 1930 a 1967. Na mesma rua, no no 21, funcionou a "Argos", loja administrada por Arlindo Gomes, com apoio de sua esposa Aracy, entre 1957 a 1967.

7 Reitero aqui o jogo de palavras que proponho com o título da exposição sobre a obra de Aracy e de seu pai, José Esteve, organizada pela Pinacoteca do Estado de São Paulo, de 9 de junho a 30 de setembro de 2012. A exposição, intitulada "Do retrato interior ao exterior do retrato - Coleção Aracy e José Esteve" reúne, desde 1920 a 1970, retratos produzidos por José Esteve no interior da Bahia até as fotografias realizadas pela filha Aracy em Salvador.

8 Em entrevista a Ricardo Sangiovanni, para o caderno "Muito", do jornal A Tarde, de Salvador, edição de junho de 2012, p. 20, Aracy apresentou essa narrativa: "Joguei bola, subi em pé de pau, usei maiô transparente. Não tinha isso de deixar de fazer as coisas porque era menina, não. Meu pai me criou assim, meio diferente". 


\section{REFERẼNCI IS}

AGAMBEN, G. Profanações. São Paulo: Boitempo, 2007.

BARTHES, R. A câmara clara. Tradução de Júlio Castañon Guimarães. Rio de Janeiro: Nova Fronteira, 1984.

DIDI-HUBERMAN, G. Diante da imagem. São Paulo: Ed. 34, 2013.

DUBOIS, P. O ato fotográficos e outros ensaios. Campinas: Papirus, 2012.

FONTCUBERTA, J. La furia de las imágenes. Barcelona: Galaxia Gutenberg, 2016.

FOUCAULT, M. Nietzsche, a genealogia e a história. In: FOUCAULT, M. Microfísica do Poder. Rio de Janeiro: Graal, 1998. p. 15-38.

FOUCAULT, M. O a priori histórico e o arquivo. In: FOUCAULT, M. A arqueologia do saber. Rio de Janeiro: Forense Universitária, 2008.

FLUSSER, V. Filosofia da caixa preta. São Paulo: Annablume, 2011.

FLUSSER, V. Gestos. São Paulo: Annablume, 2014.

FLUSSER, V. O universo das imagens técnicas: elogio da superficialidade. São Paulo: Annablume, 2008.

KOSSOY, B. Fotografia e história. São Paulo: Ateliê Editorial, 2001.

PINHEIRO, E. P. Europa, França e Bahia: difusão e adaptação de modelos urbanos (Paris, Rio e Salvador). 2. ed. Salvador: EDUFBA, 2011.

RANCIĖRE, J. O destino das imagens. Rio de Janeiro: Contraponto, 2012.

SANGIOVANNI, R. Biografia fotográfica. A Tarde, Salvador, p. 18-23, Jun. 2012. Caderno Muito. 